\section{Birding in Brazil}

When foreign visitors to Brazil think about traveling to see forests, they tend to consider only Amazonia and its rainforests. But the Atlantic Forest of southeast Brazil, with many distinct habitats that harbor at least 927 bird species, provides an extraordinarily different experience for birders and other ecotourists.

To maximize that experience, review this guide's opening chapter, which describes the region's habitats, their characteristics, and distinctive species. Each type of habitat (forests, cerrado, mangroves, highelevation grasslands) hosts particular species of birds. In addition, species of the region's northern habitats differ from those of the south, as do those found at different elevations.

\section{Visiting Brazil}

Brazil is large. Geographically it is the fifth largest nation on the planet-larger than Western Europe-and covers approximately the area of the continental United States. Travel distances are vast, requiring advance planning of itineraries. Bear in mind that the Brazilian summer (January-February) is vacation time, with many people traveling and many flights, tours, and hotels booked ahead of time. Major airports are usually located outside urban centers, so it is easy to avoid the challenges of navigating unfamiliar cities and go directly to the countryside where the birds are. Familiar car rental companies are easily found at many airports, and road conditions are generally very good in eastern and southern Brazil.

Most international flights arrive in São Paulo or Rio de Janeiro, with both offering easy access to domestic flights as well as nearby world-class birding spots. If time is short, go to the botanical gardens in both cities to see toucans, woodcreepers, guans, tanagers, and hummingbirds.

There is good birding year-round in Brazil, but it is perhaps best in September and October, the advent of the bird breeding season as well as the dry season. It can be very hot and humid in January and February (above $100{ }^{\circ} \mathrm{F} / 37^{\circ} \mathrm{C}$ ), though slightly cooler at higher altitudes. June to August is a cooler time, with São Paulo usually ranging from $50{ }^{\circ} \mathrm{F} / 10{ }^{\circ} \mathrm{C}$ to the high $80 \mathrm{~s} \mathrm{F/mid-20s} \mathrm{C}$, trending warmer northward (and down to freezing at higher elevations). During the rainy season (October-March), afternoon showers are typical.

Visiting Brazil is easier if you speak a few words of Portuguese, but English is now often spoken in major urban areas. Brazil has a reciprocal visa policy: if your country (e.g., United States, Australia, New Zealand) requires Brazilians to obtain a visa, you will need a visa to enter Brazil. A yellow fever vaccination is recommended but not required in southeastern Brazil. Polio and tetanus shots are recommended. Malaria is unusual in the region, but dengue and other mosquito-borne diseases occur in some towns. Use insect repellent as well as sunblock.

The currency in Brazil is the real (R\$). US dollars and euros are not accepted, and one must change money upon arrival in Brazil. Not all ATMs in Brazil are international, even at airports. Credit cards (especially Visa and Mastercard) are widely accepted in urban hotels and restaurants.

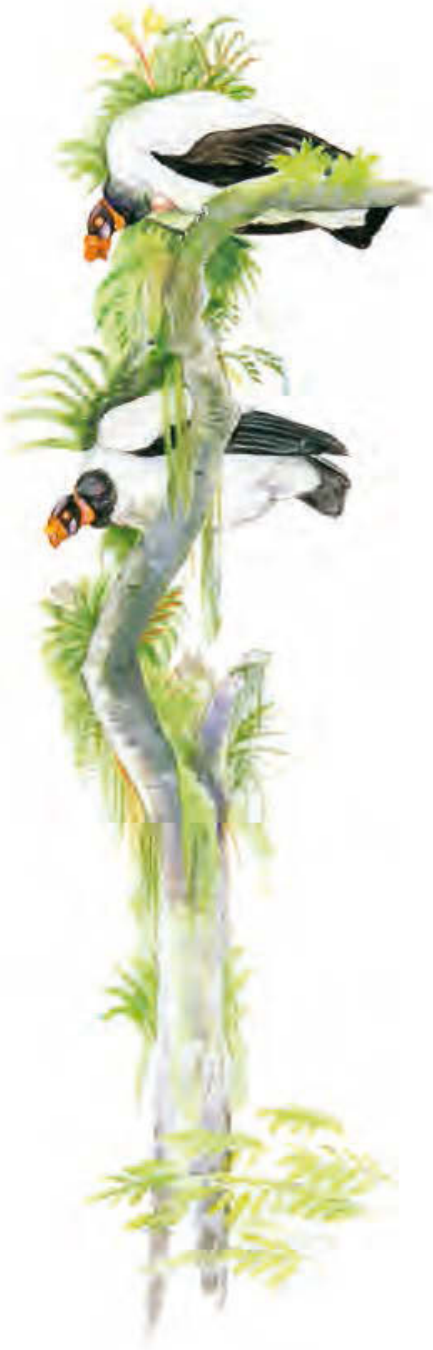

Birdwatching tourism in Brazil, including staying in ecolodges, visiting protected areas and private reserves, and hiring local guides, can indirectly increase protection of many birds such

as King Vultures, which now have only very local populations in the Atlantic Forest. 


\section{Birding in the states of São Paulo and Rio de Janeiro}

Many birders go initially to Itatiaia, the first of Brazil's majestic national parks. Located between Rio de Janeiro and São Paulo, and easily reached by car in two to three hours, it offers grand vistas and upland birding. Itatiaia boasts more than 370 species, from Green-billed Toucan to Gilt-edged and Brassy-breasted Tanager, Swallow-tailed Cotinga, and Frilled Coquette. Here, it is also possible to find highland species such as Itatiaia Spinetail, Green-crowned Plovercrest, Blackand-gold Cotinga, and twenty species of hummingbirds.

Near beautiful beaches and islands of Ubatuba and Paraty, located between São Paulo and Rio de Janeiro, lowland forests offer 400 species, including Saffron Toucanet, Channel-billed Toucan, Barethroated Bellbird, Buff-throated Purpletuft (Ubatuba), Black-hooded Antwren (Paraty), Spotted Bamboowren, Red-necked Tanager, and Long-billed Wren (in mangroves).

More than 430 species have been recorded at Intervales State Park and its buffer zone, in southern São Paulo state. There, within the largest surviving area of continuous Atlantic Forest, you may see Blackfronted Piping Guan, Long-Trained Nightjar, Helmeted Woodpecker, Serra do Mar Tyrant Manakin, Swallow-tailed Cotinga, Temminck's Seedeater, and Azure Jay.

In araucaria forest about two hours from São Paulo, Campos do Jordão is noted for Araucaria Tit-Spinetail, Vinaceous-breasted Amazon, Rustybarred Owl, and Bay-chested Warbling Finch.

In the Serra dos Órgãos area, near Rio de Janeiro, there is good birding at Teresópolis, REGUA, and Nova Friburgo, with sightings of Black Hawk-Eagle, Crescent-chested Puffbird, Brazilian Tanager, and Blue-naped Chlorophonia.

\section{Exploring further in the Southeast}

Near Belo Horizonte, Serra do Cipó's beautiful if outlandish upland landscapes offer Horned Sungem, Cipó Canastero, Gray-backed Tachuri, and Blue Finch. Other birding spots in Minas Gerais state include Serra da Canastra (with cerrado specialties such as Brazilian Merganser and Cock-tailed Tyrant) and private reserve Mata do Passarinho at Bandeira (which protects Stresemann's Bristlefront).

In Espírito Santo the best-known birding spot is Reserva da Vale (Linhares), one of the last remnants of the impressively tall lowland forest that once extended to south Bahia. This is one of the last places in the Atlantic Forest with a confirmed presence of Harpy Eagle (very rare, but known to nest here). Other species include Redbilled Curassow, Solitary Tinamou, Ochre-marked and Maroon-faced Parakeet, Reichenow's Parrot, Minute Hermit, Ocellated Poorwill, Black-cheeked Gnateater, Banded and White-winged Cotinga, and Black-headed Berryeater. For hummingbirds, such as the Frilled Coquette, go to the picturesque small town of Santa Teresa and the Augusto Ruschi Biological Reserve. Two hours away there is a possibility of finding Cherry-throated Tanager at Caetés forest (which needs protection) at Vargem Alta.

In South Bahia, Estação Veracel near Porto Seguro (famous for its beaches and excellent tourism facilities) boasts Banded and Whitewinged Cotinga, Hook-billed Hermit, Red-browed Amazon, and Blackheaded Berryeater. For Pink-legged Graveteiro, Pin-tailed Manakin, and Spot-billed Toucanet try Serra Bonita. Other good places to try are Monte Pascoal National Park and Una Biological Reserve.

The map on page i identifies some excellent birding locations, but there are also others. The Internet is a good resource for finding ecotourism pousadas (inns) that are keen to welcome birders and provide local bird guides and species lists. Look for information about towns such as Gonçalves, Ilhabela, Extrema, Angra dos Reis, Iporanga, Itanhaém, Tapiraí, and Pedra Azul.
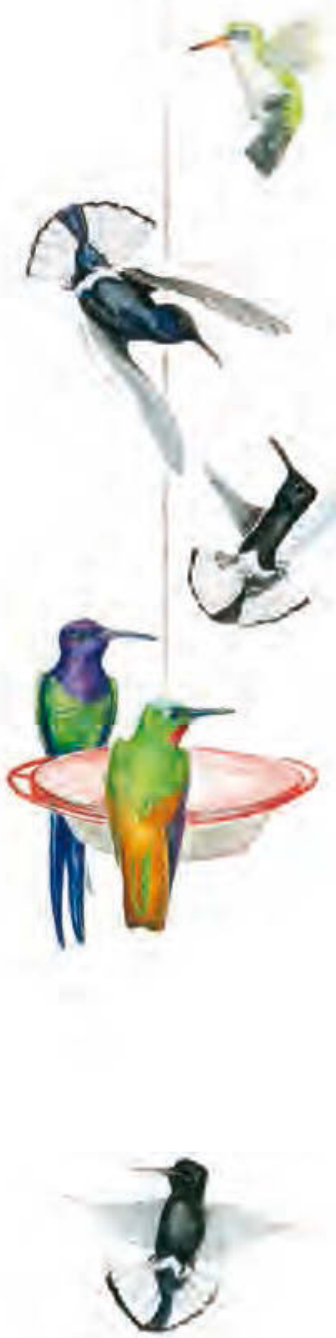

Many hummingbirds are attracted to sugar-water feeders. 
W.

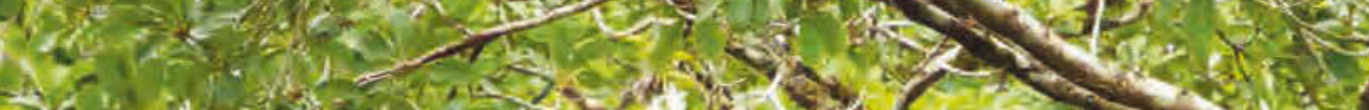

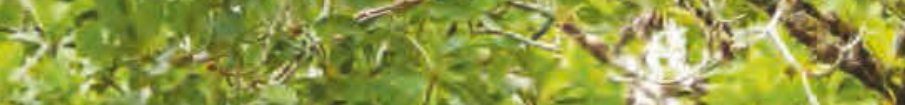

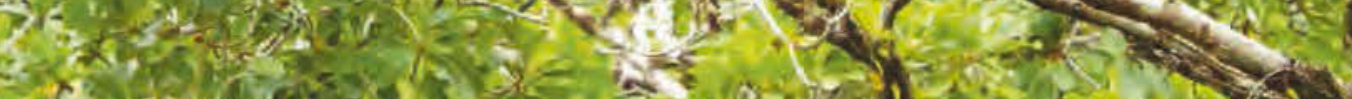

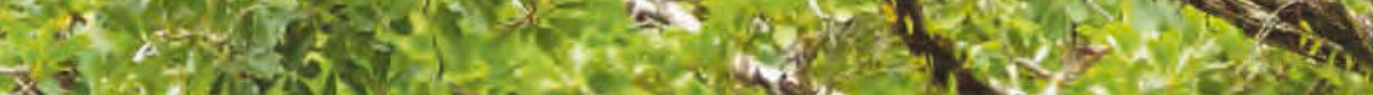

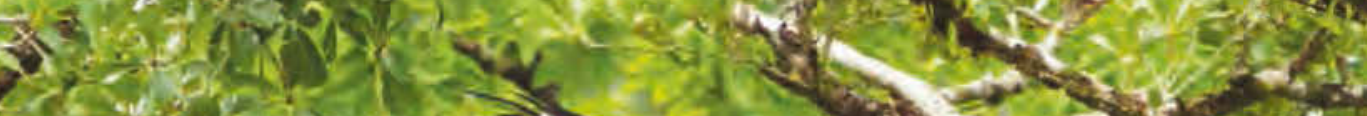

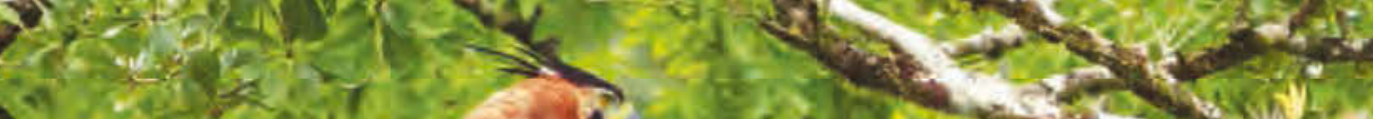
W.

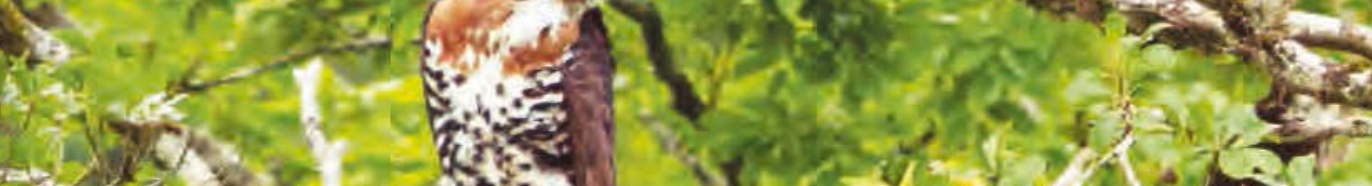

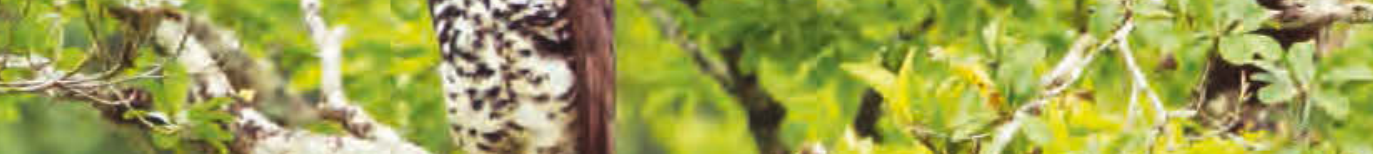

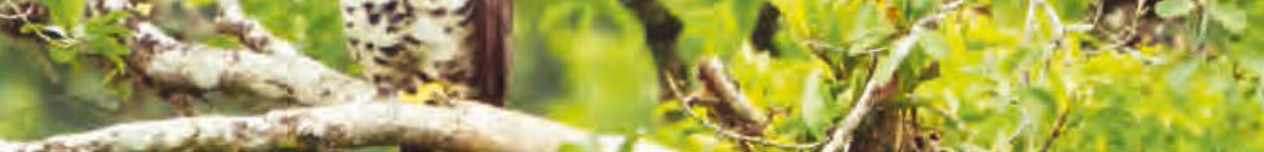

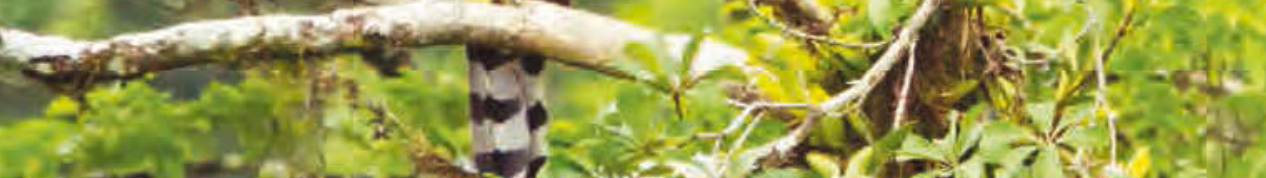

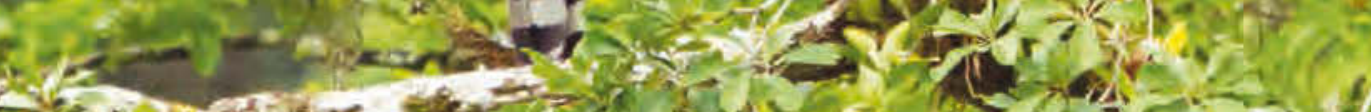

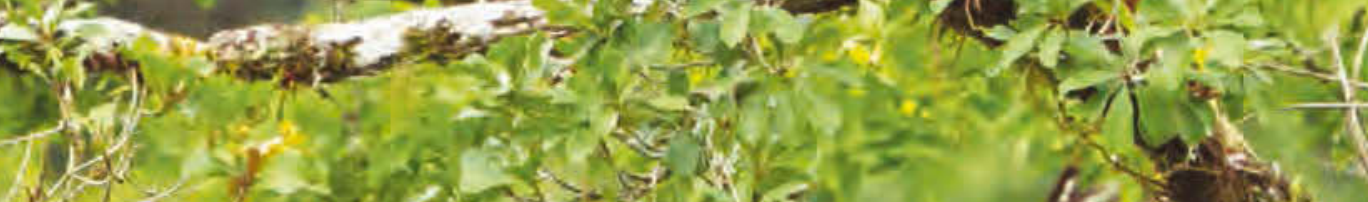
(5) is

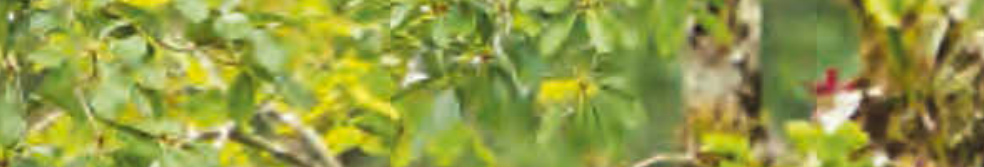
(1) (4) 